\title{
Nutrient abundance and variability from soils in the coast of king George Island
}

\author{
Andrzej Łachacz ${ }^{1}$,Barbara Kalisz ${ }^{1 *}$, Irena Giełwanowska ${ }^{2,4}$, Maria Olech ${ }^{3,4}$, Katarzyna J. \\ Chwedorzewska ${ }^{4}$, Wioleta Kellmann-Sopyła ${ }^{2}$
}

${ }^{1}$ University of Warmia and Mazury in Olsztyn, Faculty of Environmental Management and Agriculture, Department of Soil Science and Land Reclamation, Plac Lódzki 3, 10-727 Olsztyn, Poland. ${ }^{2}$ University of Warmia and Mazury in Olsztyn, Faculty of Biology and Biotechnology, Department of Plant Physiology,

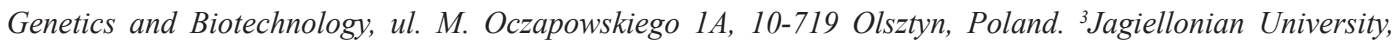
Institute of Botany, ul. Kopernika 27, 31-501 Cracow, Poland. ${ }^{4}$ Institute of Biochemistry and Biophysics of Polish Academy of Sciences, Department of Antarctic Biology, ul. Pawińskiego 5a, 02-106, Warsaw, Poland. *Corresponding author: barbara.kalisz@uwm.edu.pl

\begin{abstract}
The goal of the study was to assess the levels of plant available nutrients in the soils of the Antarctic oasis of Point Thomas in the vicinity of Polish Antarctic Station H. Arctowski. Antarctic soils are undergoing transformations in the era of climatic changes and it is important to quantify changes in soil properties and determine the relationships between soil properties and ecological gradient. Total $\mathrm{C}$ and $\mathrm{N}$ were determined using $\mathrm{CN}$ analyser, mineral forms of nitrogen were determined colorimetrically, plant available $\mathrm{P}$ and $\mathrm{K}$ was analysed with EgnerRiehm method, Mg with Schachtschabel method and $\mathrm{Fe}, \mathrm{Mn}, \mathrm{Cu}, \mathrm{Zn}$ were determined in $1 \mathrm{M} \mathrm{KCl}$ using AAS (Atomic Absorption Spectrometry) method. The amounts of analysed compounds were dependent on organic matter, which was influenced by plant succession, and in some sites by the activity of seabirds. Most of organic matter was accumulated in the vicinity of penguin colony. All studied soils were abundant in plant available forms of studied macro- and micronutrients. In addition to translocation of biogens (mainly $\mathrm{N}$ and $\mathrm{P}$ ) from the sea to the land by piscivorous birds, a dispersion of biogens on the entire ice-free area occurs. It is related to the occasional appearance of scua as well as the eolian topsoil dust input.
\end{abstract}

Keywords: Polar soils, maritime Antarctic, ornithogenic soils 


\section{Introduction}

Soil formation in Antarctica is restricted to less than $0.35 \%$ of the continent. Soils cover ice-free areas located mostly along the coastal zone of West Antarctic Peninsula (Simas et al., 2008). Those regions have the coldest climates on Earth. Therefore, the processes of mechanical weathering (frost weathering) dominate over chemical ones. The most important soil-forming factors in this region are bedrock and time (Bölter 2011; Beyer et al. 2000; Simas et al. 2015; Vlasov et al. 2005). In polar regions, a very important role in soil formation is also played by permafrost, which occurs within the first meter below the surface, which has a dominant influence on soil properties, including the circulation of water and nutrients. Antarctic soils are described as young with poor stratification (poor development of genetic horizons), high content of coarse skeletal fractions and low content of organic matter (Bölter, 2011). Generally, these are shallow soils presenting lithic or paralithic contact within the first meter of the soil profile (Francelino et $a l ., 2011)$. Soils are also influenced by cryoturbic processes - the translocation of soil materials in various directions, also upwards, as a consequence of freezing and unfreezing. In most soils, coarse mineral fractions (stones and gravel) prevail, as a result of the predominance of frost weathering. The cryoturbic processes lead to the increase of silt and clay fractions. Solifluction ("flowing" of soil on the slope, especially when the mass of soil is heavy due to high water content) and cryoturbation hamper the colonization of vascular plants and this results in stone ring polygons on plateaux and garlands on slopes (Beyer and Bölter, 2012). High spatial variability of soil-forming factors and soils occurs over meter scales (Beyer et al., 2000; Cannone et al., 2008; Smykla et al., 2015). Soils of circumpolar and high mountain regions have attracted the attention of researchers for a long time. However, despite numerous studies, these soils are still relatively poorly recognized due to their inaccessible location and extreme environmental conditions.

Climate change and the related retreat of glaciers provide the possibility to study the colonization of exposed surfaces colonization by plants and soil development (Bölter, 2011; Kabała and Zapart, 2012). Study of the processes occurring in the vicinity of glaciers can help to explain the genesis of soils occurring over large areas covered by continental glaciation in Pleistocene. Accumulation and transformation of organic matter are important processes in soil development in polar regions. Accumulation of organic matter occurs under plant communities (Otero et al., 2013). Due to specific climatic factors, especially low temperatures and a short growing season, primary production in the polar regions is very low. In the same sites and for the same reasons the mineralization of organic matter also occurs slowly (Świtoniak et al., 2014; Ping et al., 2015). Generally, the scarcity of water in the liquid state limits biological and chemical processes. However, in some habitats, high humidity also inhibits the processes of mineralization (decomposition) of soil organic matter. In these sites, high amounts of organic matter formed over the soil surface, may accumulate in the form of peat-like material. Although Antarctic regions are little exposed to direct human impact, more tourists visit these areas every year and as a result increased amounts of xenobiotics are found in the soils around scientific stations (Ugolini and Bockheim, 2008).

The soils in the Antarctic region are not abundant in nutrients. However, locally, the amount of nutrients can be high or very high, modified by organic and inorganic inputs from marine aerosols, guano deposits (mainly from penguins and pinnipeds gathering in huge breeding colonies) and marine algae (mostly 
The soils in the Antarctic region are not abundant in nutrients. However, locally, the amount of nutrients can be high or very high, modified by organic and inorganic inputs from marine aerosols, guano deposits (mainly from penguins and pinnipeds gathering in huge breeding colonies) and marine algae (mostly macroalgae) deposited on the seashore (Tatur and Myrcha, 1984; Nędzarek, 2008; Pereira et al., 2013). Large amounts of nitrogen accumulated in soils are transformed, which rate can be accelerated during warm periods/climate warming. Transformation of nitrogen forms leads to the release of nitrous oxide $\left(\mathrm{N}_{2} \mathrm{O}\right)$, which is a potent greenhouse gas (Carvajal et al., 2016). As a result of the specific soil forming process termed phosphatization, ornithogenic soils develop (Tatur and Myrcha, 1984). They have enhanced content of organic matter, including biolithic elements, such as $\mathrm{P}, \mathrm{N}, \mathrm{K}$, low soil reaction $(\mathrm{pH})$ and base saturation and are usually covered by continuous vegetation of Deschampsia antarctica and Colobanthus quitensis and/or Prasiola crispa - green algae (Androsiuk et al., 2015). Although the knowledge of geochemistry (Simas et al., 2015) in polar regions has increased in recent years, still little is known about the concentrations of nutrients available to plants. Generally, antarctic regions are little exposed to direct human impact, but more tourists visit these areas every year and consequently more xenobiotics are found in the soils around scientific stations (Ugolini and Bockheim, 2008).

The aim of this paper was to assess the levels of plant available macro- and micronutrients and their variability in soils of the Arctowski region. An important aspect of the study was to determine the relationships between soil properties and the ecological gradient (gradients created as a result of spatial shifts in land elevation, distance from the sea, etc.) and to quantify changes in soil properties which may be associated with organic carbon accumulation in the top layer of the soil profile.

\section{Material and Methods}

\subsection{Study area}

The study area was near the Polish Antarctic Station H. Arctowski situated on the western shore of Admiralty Bay, King George Island, (South Shetland Islands), which covers ca. $1310 \mathrm{~km} 2$ and is located some 100 $\mathrm{km}$ north of the Antarctic Peninsula (Birkenmajer, 2002). The ice-free area of the island covers ca. $8 \%$ and is influenced by soil forming factors (Bölter, 2011). The mean annual temperature is $-2.7^{\circ} \mathrm{C}$, and the precipitation is $510 \mathrm{~mm}$ near the station. In summer, the mean daily temperature is above $0.1{ }^{\circ} \mathrm{C}$ at sea level and precipitation is higher than $100 \mathrm{~mm}$. Favorable environmental conditions and good accessibility make the station very exposed to scientific and touristic activity. In three austral summer seasons (2006/7; 2007/8 and 2008/9) over 13 thousand tourists visited the station. During this period, the station hosted 103 expeditioners (20 in winter and 83 in summer groups) which had an impact on aspects of the environment. The soil parent material that predominates in the Arctowski region constitutes mainly volcanic rock (andesite basalts and their pyroclastics). However, in lower parts of the relief, sedimentary rocks prevail (Bölter, 2011).

During long-term monitoring studies carried out at King George Island, typical zones of colonization and primary succession on the outskirts of glaciers, further from the sea and at a higher altitude were noted. In these zones, the occurrence of various cryptograms (fungi, lichens, mosses and liverworts) and two native flowering plants, representative of the Caryophyllaceae, Colobanthus quitensis and grass Deschampsia antarctica are different. In 1985, Poa annua, an alien grass species, appeared on King George Island. It initially was found only in the immediate vicinity of the Station, but now has spread further on the island (Hughes et al., 2015). 
Soil sampling was conducted in the area of Point Thomas oasis, which is not covered by ice. The sites were chosen to represent a wide variety of major soils from the region. Selection of study sites depended on geomorphological features as well as distribution and abundance of lichens, mosses, liverworts and flowering plants. Eight sites were selected, differing in terms of the intensity of soil-forming factors such as distance from the sea (7-900 m), distance from the glacier (150$950 \mathrm{~m}$ ), altitude (1-180 $\mathrm{m}$ a.s.1.), slope and exposure, ages and stages of soil development. The sites were chosen to represent a wide variety of major soils from the region. All sites were located up to approx. $1300 \mathrm{~m}$ (Figure 1, 2, Table 1) from one another. Site 1 (Penguin Rock) and 2 (Rakusa Point) were located close to each other, but had varying distances from the sea (95 and 7 meters) and altitude (20 and $5 \mathrm{~m}$ a.s.l.) Sites 3 (III moraine of Ecology Glacier), 4 (II moraine of Ecology
Glacier) and 5 (Puchalski Grave) were also located close to each other. Site 5 (Puchalski Grave) was located in the area of an historical penguin colony, at $55 \mathrm{~m}$ a.s.1., 350 meters from the sea and approx. 700 $\mathrm{m}$ from the glacier, and was entirely covered with lichenized fungi, mosses and native flowering plants, Colobanthus quitensis and Deschampsia antarctica. Site 6 (Jersak Hills) was the most distant from the sea (Admiralty Bay), approx. $900 \mathrm{~m}$, and the highest above sea level (180 m a.s.1.). Sites 7 (the youngest moraine of Ecology Glacier) and 8 (Arctowski Station) were located at the lowest sea level, 3 and $1 \mathrm{~m}$ a.s.l. respectively. Site 5 (Puchalski Grave) was located in the area of an historical penguin colony, at $55 \mathrm{~m}$ a.s.1., 350 meters from the sea and approx. $700 \mathrm{~m}$ from the glacier, and was entirely covered with lichenized fungi, mosses and native flowering plants, Colobanthus quitensis and Deschampsia antarctica.

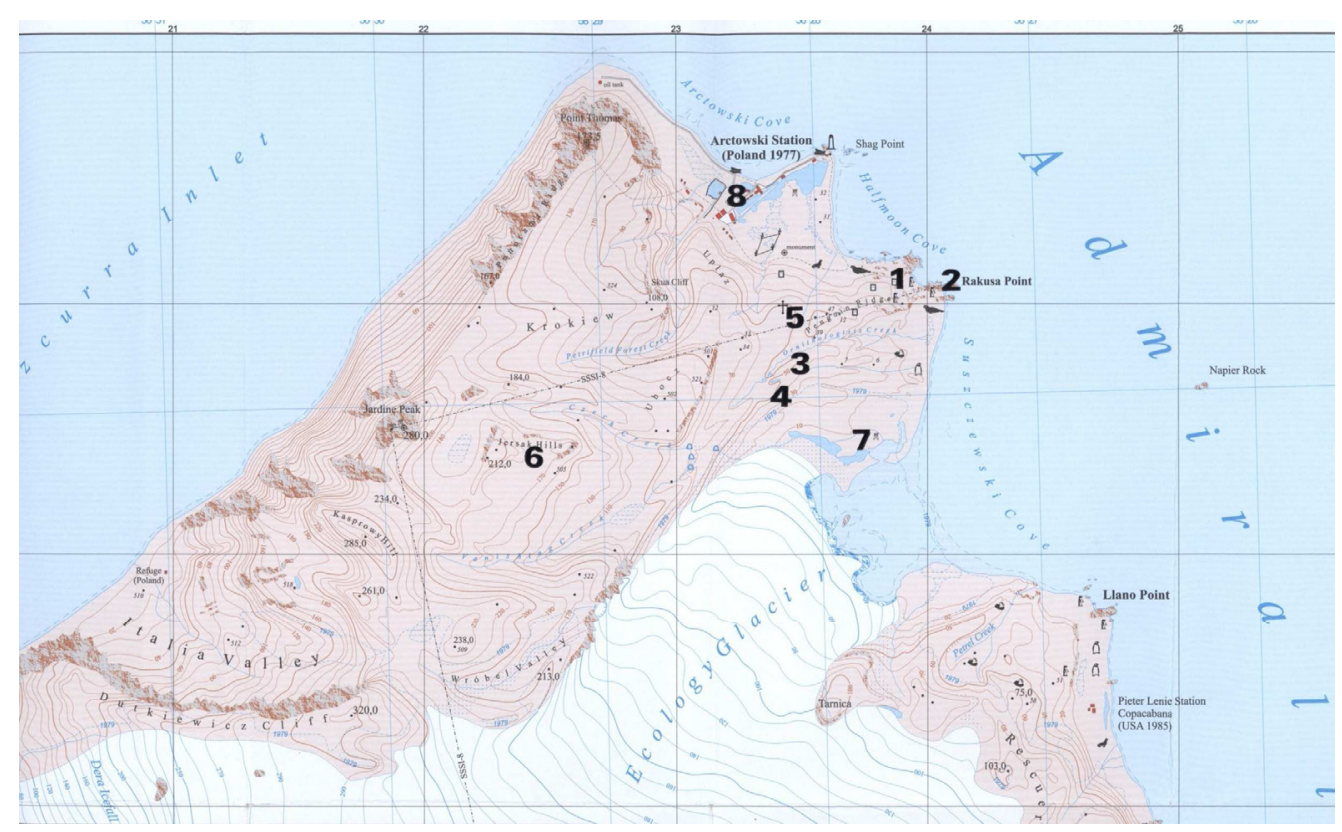

Figure 1. Location of the studied sites in the western shore of Admiralty Bay (map after Pudełko, 2002) (numbers 1-8 - indicate locations of studied sites. 

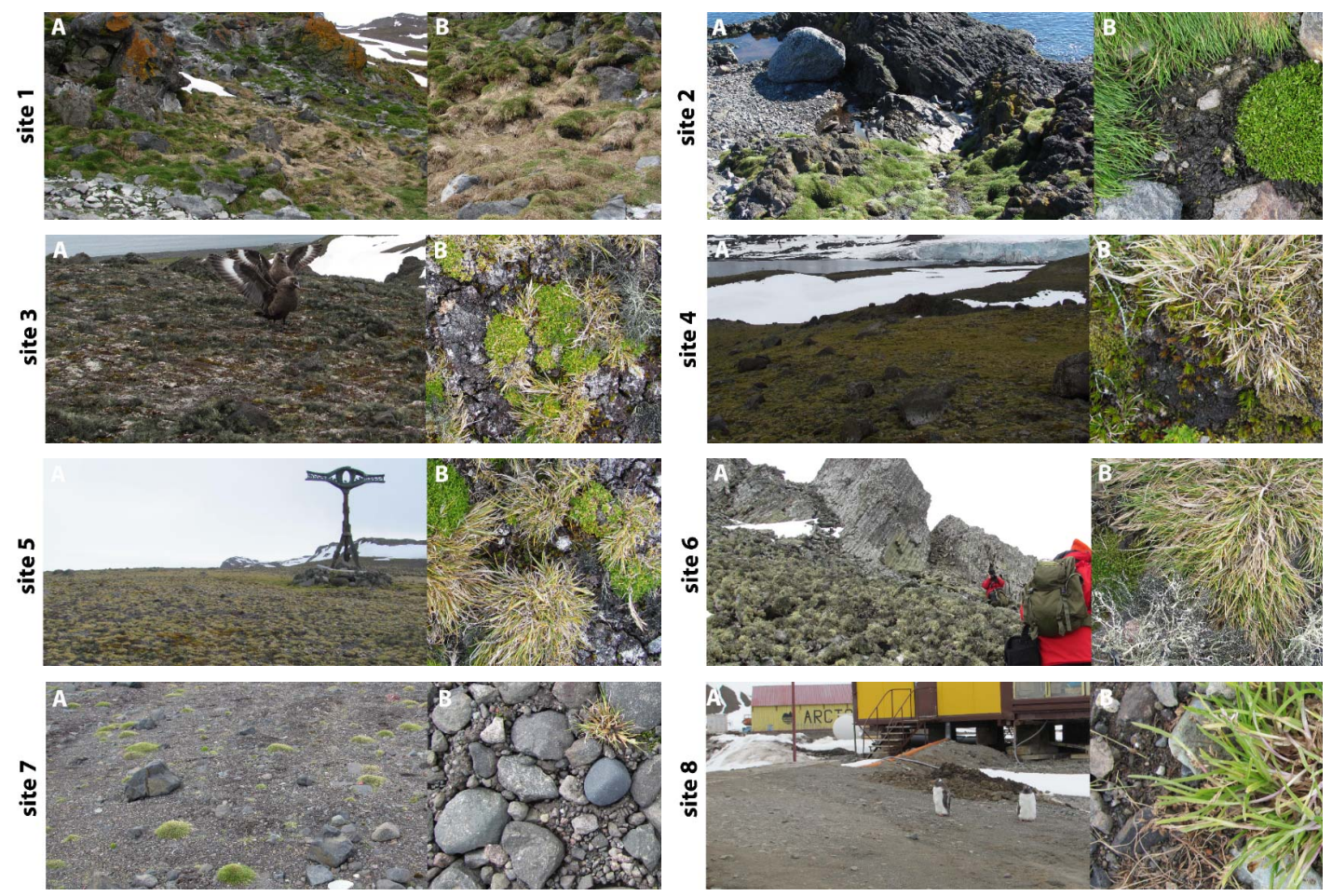

Figure 2. Examples of studied sites (Site 1 - A: Rocks below the penguins rookery, B: Deschampsia antarctica and ornithocoprogenous lichens; Site 2 - A: Rakusa Point, B: Soil in cracks with D. antarctica and Colobanthus quitensis; Site 3 - A: Antarctic tundra on III Morein of Ecology Glacier, pair of birds - south polar skua, B: Vascular plants among mosses and lichens; Site 4 - A: II Morein of Ecology Glacier, B: Plant cover of Antarctic tundra; Site 5 - A: Antarctic tundra on relatively old morein, Puchalski's grave, B: Densely covered by mosses, lichens and vascular plants; Site 6 - A: Jersak Hills, scree debris, B: D. antarctica, mosses and lichens: Usnea antarctica, U. aurantiaco-atra; Site 7 - A: Surface of fluted morein covered by scarce tussocks of plants, mainly D. antarctica, B: Young tussocks of D. antarctica and some mosses; Site 8 -A: The Arctowski Station - penguins Pygoscelis adeliae, B: Alien grass species - Poa anna (photos by I. Giełwanowska).

At each site, six soil samples were collected from an area of $10 \times 10 \mathrm{~m}$. Soil samples were taken from surface layers of $0-15 \mathrm{~cm}$ (shallower if the solid rock occurred) after removal of live vascular plant fragments, mosses and lichens. Soil samples of approx. $1 \mathrm{~kg}$ were placed into plastic bags, frozen to $-20{ }^{\circ} \mathrm{C}$, and delivered to the laboratory in this state. 
Table 1. Main characteristics of the sampling sites

\begin{tabular}{|c|c|c|c|c|c|c|c|c|}
\hline Site & $\begin{array}{l}\text { Geographical } \\
\text { coordinates }\end{array}$ & $\begin{array}{l}\text { Distance } \\
\text { to sea }(\mathrm{m})\end{array}$ & $\begin{array}{l}\text { Distance to } \\
\text { glacier (m) }\end{array}$ & $\begin{array}{l}\text { Altitude } \\
\text { (m a.s.l.) }\end{array}$ & $\begin{array}{l}\text { Slope }\left({ }^{\circ}\right) \\
\text { and aspect }\end{array}$ & $\begin{array}{l}\text { Landform and habitat } \\
\text { Soil unit: WRB 2014 }\end{array}$ & $\begin{array}{l}\text { TVC } \\
(\%) \\
\end{array}$ & Structure of vegetation (\%) \\
\hline $\begin{array}{l}1 \text { Penguin } \\
\text { Rock }\end{array}$ & $\begin{array}{l}62^{\circ} 09^{\prime} 44.7 ” \mathrm{~S} \\
58^{\circ} 27^{\prime} 45.9^{\prime \prime} \mathrm{W}\end{array}$ & 95 & 800 & 20 & $25-35, \mathrm{NE}$ & $\begin{array}{l}\text { bare rocks with soils } \\
\text { enriched by penguins; } \\
\text { Eutric Skeletic Lithic } \\
\text { Leptosol (Humic, } \\
\text { Ornithic, Protic) }\end{array}$ & 85 & $\begin{array}{l}\text { open with Deschampsia antarctica }(60 \%) \text {, } \\
\text { mosses }(15 \%) \text {, crustose lichens }(15 \%) \text { and } \\
\text { singly Colobanthus quitensis }(10 \%)\end{array}$ \\
\hline $\begin{array}{l}2 \text { Rakusa } \\
\text { Point }\end{array}$ & $\begin{array}{l}62^{\circ} 09^{\prime} 45.0^{\prime \prime} \mathrm{S} \\
58^{\circ} 27^{\prime} 25.1 ’ \mathrm{~W}\end{array}$ & 7 & 700 & 5 & $35-40, \mathrm{NE}$ & $\begin{array}{l}\text { slope rocks, soils in } \\
\text { cracks and hollows; } \\
\text { Eutric Skeletic Lithic } \\
\text { Leptosol (Hyperhumic, } \\
\text { Ornithic, Protic) }\end{array}$ & 70 & $\begin{array}{l}\text { open with singly Colobanthus quitensis } \\
(4 \%) \text {, Deschampsia antarctica }(10 \%) \text {, } \\
\text { mosses }(6 \%) \text { and crustose lichens }(80 \%)\end{array}$ \\
\hline $\begin{array}{l}3 \text { III Moraine } \\
\text { of Ecology } \\
\text { Glacier } \\
\text { (MEG) }\end{array}$ & $\begin{array}{l}62^{\circ} 09^{\prime} 55.8^{\prime \prime} \mathrm{S} \\
58^{\circ} 27^{\prime} 40.2^{\prime \prime} \mathrm{W}\end{array}$ & 800 & 300 & 70 & $25-30, \mathrm{NW}$ & $\begin{array}{l}\text { tundra on slope; Skeletic } \\
\text { Protic Turbic Cryosol } \\
\text { (Eutric, Humic, } \\
\text { Ornithic) }\end{array}$ & 100 & $\begin{array}{l}\text { close with Colobanthus quitensis }(10 \%) \text {, } \\
\text { Deschampsia antarctica }(30 \%) \text {, mosses } \\
(10 \%) \text { and fruticose and foliose lichens } \\
(50 \%)\end{array}$ \\
\hline 4 II MEG & $\begin{array}{l}62^{\circ} 09^{\prime} 56.8^{\prime \prime} \mathrm{S} \\
58^{\circ} 28^{\prime} 03.0^{\prime \prime} \mathrm{W}\end{array}$ & 800 & 250 & 60 & $10-15, \mathrm{NW}$ & $\begin{array}{l}\text { tundra on slope; Eutric } \\
\text { Protic Skeletic Regosol } \\
\text { (Turbic) }\end{array}$ & 85 & $\begin{array}{l}\text { open with Colobanthus quitensis }(10 \%) \text {, } \\
\text { Deschampsia antarctica }(20 \%) \text {, mosses } \\
(35 \%) \text { and fruticose and foliose lichens } \\
(35 \%)\end{array}$ \\
\hline $\begin{array}{l}5 \text { Puchalski } \\
\text { Grave }\end{array}$ & $\begin{array}{l}62^{\circ} 09^{\prime} 48.0 ” \mathrm{~S} \\
58^{\circ} 28^{\prime} 09.0^{\prime \prime} \mathrm{W}\end{array}$ & 350 & 700 & 55 & $20-25, \mathrm{~N}$ & $\begin{array}{l}\text { tundra on slope; Skeletic } \\
\text { Protic Turbic Cryosol } \\
\text { (Dystric, Humic, } \\
\text { Ornithic) }\end{array}$ & 100 & $\begin{array}{l}\text { close with Colobanthus quitensis }(15 \%) \text {, } \\
\text { Deschampsia antarctica }(15 \%) \text {, mosses } \\
(20 \%) \text { and fruticose and foliose lichens } \\
(50 \%)\end{array}$ \\
\hline 6 Jersak Hills & $\begin{array}{l}62^{\circ} 10^{\prime} 07.0^{\prime \prime} \mathrm{S} \\
58^{\circ} 28^{\prime} 55.0^{\prime \prime} \mathrm{W}\end{array}$ & 900 & 650 & 180 & $35-45, \mathrm{~N}$ & $\begin{array}{l}\text { scree debris; Eutric } \\
\text { Protic Skeletic Leptic } \\
\text { Regosol (Turbic) }\end{array}$ & 85 & $\begin{array}{l}\text { open with crustose, fruticose and foliose } \\
\text { lichens }(60 \%) \text {, mosses }(30 \%) \text {, and singly } \\
\text { Colobanthus quitensis }(5 \%) \text { and } \\
\text { Deschampsia antarctica }(5 \%)\end{array}$ \\
\hline $\begin{array}{l}7 \text { The } \\
\text { Youngest } \\
\text { MEG }\end{array}$ & $\begin{array}{l}62^{\circ} 10^{\prime} 05.0^{\prime \prime} \mathrm{S} \\
58^{\circ} 27^{\prime} 45.0^{\prime \prime} \mathrm{W}\end{array}$ & 500 & 150 & 3 & 0 & $\begin{array}{l}\text { fluted moraine; Eutric } \\
\text { Skeletic Protic Regosol } \\
\text { (Turbic) }\end{array}$ & 15 & $\begin{array}{l}\text { open with mosses }(40 \%) \text {, fruticose and } \\
\text { foliose lichens }(40 \%) \text {, singly Colobanthus } \\
\text { quitensis }(10 \%) \text { and Deschampsia antarctica } \\
(10 \%)\end{array}$ \\
\hline $\begin{array}{l}8 \text { Arctowski } \\
\text { Station }\end{array}$ & $\begin{array}{l}62^{\circ} 09^{\prime} 34.0 \text { '”S } \\
58^{\circ} 28^{\prime} 18.0^{\prime \prime} \mathrm{W}\end{array}$ & 120 & 950 & 1 & 0 & $\begin{array}{l}\text { Base station, soil } \\
\text { mechanically altered by } \\
\text { human activities; } \\
\text { Skeletic Eutric Fluvisol } \\
\text { (Turbic) }\end{array}$ & 55 & $\begin{array}{l}\text { open with singly Colobanthus quitensis } \\
(15 \%) \text {, Deschampsia antarctica }(25 \%) \text {, Poa } \\
\text { annua }(10 \%) \text {, mosses }(25 \%) \text { and fruticose, } \\
\text { foliose and crustose lichens }(25 \%)\end{array}$ \\
\hline
\end{tabular}

\subsection{Laboratory analyses}

After unfreezing, mineral forms of nitrogen $\left(\mathrm{N}^{-\mathrm{NO}_{3}}\right.$ and $\mathrm{N}^{-\mathrm{NH}_{4}}$ ) in the samples were immediately measured after extraction in $0.01 \mathrm{M} \mathrm{CaCl}_{2} \mathrm{dm}^{-3}$ by the colorimetry flow method. Other analyses were carried out in air-dry soil samples after sieving through a $2.0 \mathrm{~mm}$ mesh using standard soil laboratory methods. Soil texture of finer fractions (diameter less than 2.00 $\mathrm{mm}$ ) was analysed using laser diffraction method with Mastersizer 2000 (Malvern Instruments Ltd., UK). Loss-on-ignition (LOI) was determined after dry ashing of soil samples for 6 hours at a temperature of $550^{\circ} \mathrm{C}$ and hereafter assumed to represent the organic matter (OM) content. Total organic carbon (TOC) and total nitrogen $(\mathrm{TN})$ contents were measured with a Vario Max Cube CN analyser (Elementar Analysensysteme GmbH, Germany).

Soil reaction $(\mathrm{pH})$ was determined potentiometrically in deionized water and in potassium chloride solution $\left(1 \mathrm{M} \mathrm{KCl} \mathrm{dm}^{-3}\right.$ ) (van Reeuwijk, 2002). The analyses of LOI, TOC, TN were performed in triplicate with the results expressed as the arithmetic mean. The content of exchangeable cations $\left(\mathrm{Ca}^{2+}, \mathrm{Mg}^{2+}, \mathrm{K}^{+}, \mathrm{Na}^{+}\right)$ was measured after extraction in $1 \mathrm{M} \mathrm{CH}_{3} \mathrm{COONH}_{4}$, at $\mathrm{pH}$ 7.0. The amount of hydrogen ion $\left(\mathrm{H}^{+}\right)$was measured with titration method after extraction in $\mathrm{BaCl}_{2}$, pH 7.0 (van Reeuwijk, 2002). 
The content of plant available phosphorus and potassium was analysed using Egner-Riehm method (Egnér at al., 1960) in $0.04 \mathrm{M} \mathrm{C}_{6} \mathrm{H}_{10} \mathrm{CaO}_{6}$ (calcium lactate) $+0.02 \mathrm{M} \mathrm{HCl}$ at $\mathrm{pH} 3.7$ (soil to solution ratio 1:20, extraction time $120 \mathrm{~min}$ ). The Egner-Riehm method is widely used in central European countries for fertilizer recommendations (Fotyma and Dobers, 2008). The content of plant available magnesium was analysed with Schachtschabel method after extraction in calcium chloride $\left(0.0125 \mathrm{M} \mathrm{CaCl}_{2} \mathrm{dm}^{-3}\right)$, soil to solvent ratio 1:20, stirred for 1 hour, and measured using AAS (Atomic Absorption Spectrometry) apparatus (Solaar 969 Pye Unicam, UK). The content of potentially labile forms of $\mathrm{Fe}, \mathrm{Mn}, \mathrm{Zn}$ and $\mathrm{Cu}$ was measured with AAS after extraction in $1 \mathrm{~mol} \mathrm{HCl} \mathrm{dm-}$ 3. All results are expressed in an oven-dry soil weight basis (temperature of drying $105^{\circ} \mathrm{C}$ ).

\subsection{Statistical analyses}

Pearson's linear correlations were used to assess relationships between soil properties studied. Differences in soil properties and nutrients among the eight studied localities were analysed by the Kruskal-Wallis rank sum test. If differences were observed at $p<0.05$, Dunn's post-hoc test for multiple comparisons was then used. The nonparametric Kruskal-Wallis test was used together with Dunn's post-hoc test because the data did not meet the assumptions of one way Anova. All statistical analyses were performed using STATISTICA 10 (StatSoft, Poland).

Principal component analysis (PCA) was applied to show relationships between studied variables as well as between studied localities. A set of 22 original variables was transformed into a set of orthogonal variables (principal components). Due to the differences in units of the variables, the data were subjected to standardization, and the principal components were calculated based on the correlation matrix.

\section{Results}

\subsection{General site and soil characteristics}

The first two sites (Penguin Rock, Rakusa Point) are similar (Table 1). They are the basalt rock outcrops, where soils have developed only in rock crevices. Site 1 is influenced by the nutrient-rich waters flowing from the penguin area. Site 2 is located in the immediate vicinity of the Adelie penguins (Pygoscelis adeliae) rookery. The soils at these sites were classified (according to IUSS Working Group WRB, 2015) as Eutric Skeletic Nudilithic Leptosol (Arenic, Humic, Ornithic, Protic). At site 1 ornithocoprophilous species of lichens prevail: Caloplaca hookeri, C. regalis, Lecania brialmontii, Physcia caesia, Turgidosculum complicatulum, Xanthoria candelaria. Prasiola crispa, a green algae also occurs extensively. Vascular plants grow abundantly, but only on the side of penguin migration routes. At site 2, located on the sea shore on the rocks next to the ornitocoprophilous lichens, Caloplaca cirrochrooides, Lecania brialmontii, Ramalina terebrata, Turgidosculum complicatulum and halophilous species, mainly Verrucaria tesselatula appeared. Also, Prasiola crispa occurs extensively.

Site 3 is a sloping edge of relatively old fluted moraine. Strongly gravelled soils are covered by Antarctic tundra. Mosses - Polytrichastrum alpinum and lichens: Bryoria forsteri, Cetraria aculeata, Sphaerophorus globosus, Usnea antarctica - in addition to two species of vascular plants occur. The nests of south polar skua (Catharacta maccormicki and C. antartica) are also present. Site 3 is the location of a former penguin rookery with relict influences of bird species: Pygoscelis adeliae, P. antarctica, P. papua, Larus dominicanus and pinnipeds mammals (Pinnipedia) visible. The soil was classified as Skeletic Protic Turbic Cryosol (Arenic, Eutric, Humic, Ornithic). 
Site 4 is similar to 3 , but younger. The plant cover is less and in addition to vascular plants the amount of lichens such as Cetraria aculeata, Leptogium puberulum and Usnea antarctica is greater. The soil was classified as Eutric Protic Skeletic Regosol (Loamic, Turbic).

Site 5 is a relatively old moraine. On the basaltic debris, Antarctic tundra developed. Mosses and lichens prevail: Polytrichastrum alpinum, Polytrichum piliferum, Ochrolechia frigida and $O$. parella, which together with vascular plants make a dense carpet. The gravelly material is water permeable and welldrained. Nowadays skua nests are present, but it was formerly a penguin rookery. The soil was classified as Skeletic Protic Turbic Cryosol (Arenic, Dystric, Humic, Ornithic).

At site 6, basalt rock outcrops occur. The soil samples were taken from a scree debris located below. The proportion of vascular plants is small, and lichens prevail: Cladonia borealis, Himantormia lugubris, Leptogium puberulum, Placopsis parella, Parmelia saxatilis, Stereocaulon glabrum, Umbilicaria antarctica, Usnea antarctica, U. aurantiaco-atra. The soil was classified as Eutric Protic Skeletic Leptic Regosol (Arenic, Humic, Turbic).

Site 7 is located on the youngest fluted moraine with rich petrographic composition. There is a large amount of stones and the least plant cover among all studied sites. The age of vascular plants is as follows: Colobanthus quitensis approx. 10 years, and Deschampsia antarctica approx. 3-5 years. The soil was classified as Eutric Protic Skeletic Protic Regosol (Loamic).

Site 8 is located near the Arctowski Station. The sea sands and fluvio-glacial sands were mechanically altered. The vegetation cover was small due to mechanical turbation by people and vehicles. In addition to two native vascular plants, an invasive grass ( $\mathrm{Poa}$ annua) and chlorophyte algae (Prasiola crispa) occur. The soil was classified as Skeletic Eutric Fluvisol (Arenic).

Except for the surroundings of the Arctowski Station (site 8 ) human impact on soil and vegetation is minimal, limited to occasional trampling during walking to reach the study points. In contrast, the soils in the vicinity of the research station are exposed to intensive human activity. The soils are frequently and regularly mixed and translocated by the movement of vehicles (mechanical disturbance of the soil surface by heavy caterpillar vehicles). Also, leakage of fuel and pollution with heavy metals and xenobiotics associated with wastes and deposition of dust occurs.

\subsection{Soil texture}

The investigated soils are rich in gravel particles, which is typical for polar regions. Among fractions with diameter less than $2.0 \mathrm{~mm}$, sand prevailed, which enabled classification of the soils of sites 1,2, 3, 5, 6 and 8 as $\mathrm{S}-$ sand texture class, and the soils of sites 4 and 7 as SL - sandy loam class (Table 2). In the soils of sites 4 and 7, the sand fraction was lower and amounted to $62.45 \%$ and $65.21 \%$, respectively and the silt fraction amounted to $34.42 \%$ and $31.03 \%$, respectively. The silt fraction in the investigated soils ranged widely, with a coefficient of variation $(\mathrm{CV})$ amounting to $78.62 \%$, which was related to the process of frost weathering. The clay fraction is low, $1.09 \%$ on average, with a high coefficient of variation (132.16\%). The differences in the proportions of sand, silt and clay were significant, especially between sites 1, 2 and 4, 7 (Table 2). 
Table 2. Mean values of general soil properties with standard deviation (SD) and coefficient of variation (CV, $\%$ ). In each column, significant differences observed at $p<0.05$ after the Kruskal-Wallis test followed by Dunn's post-hoc test are marked by different letters.

\begin{tabular}{|c|c|c|c|c|c|c|c|c|c|c|c|c|c|c|}
\hline $\begin{array}{l}\text { Site } \\
\text { No. }\end{array}$ & & $\begin{array}{l}\text { Sand } \\
0.05-2.0 \\
\text { mm }\end{array}$ & $\begin{array}{l}\text { Silt } \\
0.002-0.05 \\
\text { mm }\end{array}$ & $\begin{array}{l}\text { Clay } \\
<0.002 \\
\mathrm{~mm}\end{array}$ & $\begin{array}{l}\text { USDA } \\
\text { texture }\end{array}$ & $\begin{array}{l}\text { LOI } \\
\%\end{array}$ & $\begin{array}{l}\text { TOC } \\
\mathrm{g} \mathrm{kg}^{-1}\end{array}$ & $\begin{array}{l}\text { TN } \\
\text { g kg }^{-1}\end{array}$ & TOC:TN & $\begin{array}{l}\mathrm{pH} \\
\mathrm{H}_{2} \mathrm{O}\end{array}$ & $\begin{array}{l}\mathrm{pH} \\
\mathrm{KCl}\end{array}$ & $\begin{array}{l}\mathbf{H}^{+} \\
\text {cmol}(+) \\
\mathbf{k g}^{-1}\end{array}$ & $\begin{array}{l}\text { CEC } \\
\text { cmol(+) }_{\mathbf{k g}^{-1}}\end{array}$ & $\begin{array}{l}\text { BS } \\
\%\end{array}$ \\
\hline \multirow[t]{3}{*}{1} & Mean & $95.91^{b}$ & $4.09^{\mathrm{ba}}$ & $0.00^{\mathrm{a}}$ & sand & $7.24^{\text {bcd }}$ & $48.74^{\mathrm{bc}}$ & $6.86^{\mathrm{b}}$ & $7.20^{\mathrm{a}}$ & $5.54^{\mathrm{a}}$ & $4.76^{\mathrm{bc}}$ & $9.38^{\mathrm{bc}}$ & $29.46^{\mathrm{ab}}$ & $68.30^{\mathrm{abc}}$ \\
\hline & SD & 0.92 & 0.92 & 0.00 & & 1.06 & 9.49 & 1.13 & 1.45 & 0.63 & 0.93 & 2.04 & 2.63 & 5.60 \\
\hline & CV\% & 0.96 & 22.55 & 0.00 & & 14.59 & 19.48 & 16.42 & 20.12 & 11.32 & 19.62 & 21.74 & 8.94 & 8.20 \\
\hline \multirow[t]{3}{*}{2} & Mean & $96.62^{b}$ & $3.38^{\mathrm{a}}$ & $0.00^{\mathrm{a}}$ & sand & $12.46^{\mathrm{d}}$ & $89.09^{c}$ & $8.86^{\mathrm{b}}$ & $9.84^{\mathrm{a}}$ & $5.70^{\mathrm{a}}$ & $4.22^{\mathrm{abc}}$ & $10.11^{\mathrm{bc}}$ & $36.71^{\mathrm{b}}$ & $73.13^{\mathrm{abc}}$ \\
\hline & SD & 0.86 & 0.86 & 0.00 & & 4.77 & 49.06 & 4.40 & 1.96 & 0.30 & 0.24 & 4.04 & 4.74 & 8.14 \\
\hline & $\mathrm{CV}$ & 0.89 & 25.31 & 0.00 & & 38.27 & 55.07 & 49.61 & 19.92 & 5.21 & 5.60 & 39.95 & 12.91 & 11.13 \\
\hline \multirow[t]{3}{*}{3} & Mean & $90.00^{\mathrm{ab}}$ & $9.71^{\mathrm{abc}}$ & $0.29^{\mathrm{ab}}$ & sand & $6.36^{\text {abcd }}$ & $37.40^{\mathrm{abc}}$ & $2.08^{\mathrm{ab}}$ & $19.92^{\mathrm{ab}}$ & $5.84^{\mathrm{ab}}$ & $3.85^{\mathrm{ab}}$ & $10.83^{\text {bc }}$ & $28.25^{\mathrm{ab}}$ & $62.15^{\mathrm{ab}}$ \\
\hline & SD & 4.42 & 4.02 & 0.45 & & 2.84 & 23.81 & 1.36 & 7.10 & 0.18 & 0.16 & 2.97 & 4.08 & 7.84 \\
\hline & $\mathrm{CV}$ & 4.91 & 41.44 & 154.68 & & 44.66 & 63.68 & 65.58 & 35.65 & 3.17 & 4.25 & 27.39 & 14.44 & 12.61 \\
\hline \multirow[t]{3}{*}{4} & Mean & $62.45^{\mathrm{a}}$ & $34.42^{\mathrm{c}}$ & $3.13^{\mathrm{bc}}$ & sandy & $2.70^{\mathrm{ab}}$ & $6.32^{\mathrm{a}}$ & $0.19^{\mathrm{a}}$ & $34.59^{b}$ & $6.55^{\mathrm{abc}}$ & $4.59^{\mathrm{bc}}$ & $1.45^{\mathrm{ab}}$ & $30.01^{\mathrm{ab}}$ & $95.17^{\mathrm{cd}}$ \\
\hline & SD & 3.41 & 3.13 & 0.31 & loam & 0.34 & 1.11 & 0.04 & 5.79 & 0.15 & 0.13 & 0.21 & 0.80 & 0.80 \\
\hline & $\mathrm{CV}$ & 5.46 & 9.08 & 9.78 & & 12.44 & 17.65 & 21.29 & 16.73 & 2.33 & 2.88 & 14.86 & 2.67 & 0.84 \\
\hline \multirow[t]{3}{*}{5} & Mean & $91.68^{\mathrm{ab}}$ & $8.27^{\mathrm{ab}}$ & $0.05^{\mathrm{ab}}$ & sand & $8.25^{\mathrm{cd}}$ & $49.17^{\mathrm{bc}}$ & $2.93^{\mathrm{ab}}$ & $16.22^{\mathrm{ab}}$ & $5.47^{\mathrm{a}}$ & $3.49^{\mathrm{a}}$ & $18.83^{\mathrm{c}}$ & $28.44^{\mathrm{ab}}$ & $33.54^{\mathrm{a}}$ \\
\hline & SD & 3.18 & 3.12 & 0.08 & & 2.65 & 22.93 & 0.80 & 3.26 & 0.28 & 0.15 & 1.84 & 2.59 & 6.52 \\
\hline & $\mathrm{CV}$ & 3.47 & 37.75 & 143.12 & & 32.09 & 46.63 & 27.26 & 20.10 & 5.15 & 4.39 & 9.76 & 9.11 & 19.43 \\
\hline \multirow[t]{3}{*}{6} & Mean & $85.67^{\mathrm{ab}}$ & $13.70^{\mathrm{abc}}$ & $0.64^{\mathrm{abc}}$ & sand & $4.50^{\text {abcd }}$ & $20.32^{\mathrm{abc}}$ & $1.03^{\mathrm{ab}}$ & $20.64^{\mathrm{ab}}$ & $6.19^{\mathrm{abc}}$ & $4.22^{\mathrm{bc}}$ & $4.65^{\mathrm{abc}}$ & $28.80^{\mathrm{ab}}$ & $83.58^{\text {abcd }}$ \\
\hline & SD & 2.16 & 1.90 & 0.28 & & 0.78 & 6.02 & 0.40 & 3.24 & 0.30 & 0.24 & 3.38 & 1.19 & 12.69 \\
\hline & $\mathrm{CV}$ & 2.52 & 13.88 & 43.60 & & 17.42 & 29.62 & 39.49 & 15.70 & 4.68 & 5.79 & 72.63 & 4.13 & 15.19 \\
\hline \multirow[t]{3}{*}{7} & Mean & $65.21^{\mathrm{a}}$ & $31.03^{\mathrm{bc}}$ & $3.75^{\mathrm{c}}$ & sandy & $2.33^{\mathrm{a}}$ & $8.53^{\mathrm{ab}}$ & $0.17^{\mathrm{a}}$ & $50.82^{b}$ & $6.89^{\mathrm{bc}}$ & $5.65^{\mathrm{c}}$ & $0.65^{\mathrm{a}}$ & $27.80^{\mathrm{a}}$ & $97.66^{\mathrm{d}}$ \\
\hline & SD & 4.12 & 3.59 & 0.55 & loam & 0.17 & 2.04 & 0.04 & 11.02 & 0.30 & 0.43 & 0.15 & 0.85 & 0.61 \\
\hline & $\mathrm{CV}$ & 6.32 & 11.55 & 14.76 & & 7.13 & 23.86 & 24.70 & 21.68 & 4.32 & 6.02 & 23.88 & 3.04 & 0.62 \\
\hline \multirow[t]{3}{*}{8} & Mean & $86.80^{\mathrm{ab}}$ & $12.32^{\mathrm{abc}}$ & $0.88^{\mathrm{abc}}$ & sand & $3.56^{\mathrm{abc}}$ & $6.22^{\mathrm{a}}$ & $0.19^{\mathrm{a}}$ & $37.24^{\mathrm{b}}$ & $6.97^{c}$ & $4.50^{\mathrm{bc}}$ & $1.58^{\mathrm{ab}}$ & $29.44^{\mathrm{ab}}$ & $94.62^{\text {bcd }}$ \\
\hline & SD & 5.35 & 4.88 & 0.47 & & 0.55 & 1.12 & 0.09 & 11.48 & 0.15 & 0.13 & 0.20 & 1.41 & 0.74 \\
\hline & $\mathrm{CV}$ & 6.16 & 39.62 & 53.06 & & 15.44 & 18.02 & 46.70 & 30.82 & 2.22 & 2.98 & 12.79 & 4.80 & 0.79 \\
\hline \multirow{3}{*}{$\begin{array}{l}\text { All } \\
\text { sites }\end{array}$} & Mean & 84.29 & 14.61 & 1.09 & loamy & 5.93 & 33.22 & 2.79 & 24.56 & 6.14 & 4.41 & 7.18 & 29.86 & 76.02 \\
\hline & SD & 12.89 & 11.49 & 1.44 & sand & 3.82 & 33.69 & 3.52 & 15.49 & 0.64 & 0.71 & 6.32 & 3.66 & 21.46 \\
\hline & $\mathrm{CV}$ & 15.29 & 78.62 & 132.16 & & 64.45 & 101.40 & 126.12 & 63.06 & 10.37 & 16.03 & 87.93 & 12.27 & 28.23 \\
\hline
\end{tabular}

\subsection{General chemical soil properties}

The amount of OM ranged widely $-2.33-12.46 \%$ on average (Table 2). The organic matter content was related to plant cover and the activities of avifauna. The lowest level of OM was found in the soils at site 7 (the youngest moraine of Ecology Glacier) and the highest at site 2 (penguin area). OM and TOC are always closely related and the average TOC content amounted to $33.22 \mathrm{~g} \mathrm{~kg}^{-1}$, with a high coefficient of variation (101.4\%). The differences in TOC amounts were significant, especially between sites 1,2 and 4, 8 (Table 2). TN content ranged between $0.17 \mathrm{~g} \mathrm{~kg}^{-1}$ and $8.86 \mathrm{~g} \mathrm{~kg}-1$ with a higher $\mathrm{CV}$ than in case of TOC. The highest TN content was found in the soils at sites 2 and 1 (respectively 8.86 and $6.86 \mathrm{~g} \mathrm{~kg}^{-1}$ ), which is related to the activity of avifauna. The average content of nitrogen in all soils amounted to $2.79 \mathrm{~g} \mathrm{~kg}^{-1}$, with coefficient of variation of $126.12 \%$. The differences in TN amounts were significant, especially between sites 1, 2 and 4, 7, 8 (Table 2). The ratio of TOC and TN was wide (7.20-50.82), with coefficient of variation of $63.06 \%$. The narrowest TOC/TN ratio was found in the soils at sites 1 and 2. The widest TOC/TN ratio was found in the soils at sites 4,7 and 8 , where it amounted to $34.59,50.82$ and 37.24 , respectively. The wide TOC/TN ratio suggests a deficit of nitrogen, inhibited decomposition of plant remnants and accumulation of organic peat-like material. Soil reaction ranged from acidic to neutral. The lowest $\mathrm{pH}$ values were found in the soils at sites 1,2,3 and 5. $\mathrm{pH}$ values correlated with the amount of exchangeable hydrogen which ranged from 0.65 to $18.83 \mathrm{cmol}(+) \mathrm{kg}^{-1}$, with a high coefficient of variance $(87.93 \%)$. In contrast, the CEC had little variation (12.27\%). Base saturation (BS) amounted to $76.02 \%$ on average, with a moderate 
coefficient of variation (28.23\%). The lowest BS was found in the soil at site $5(33.54 \%)$, and the highest in the soils at sites 4,7 and $8(>90 \%)$. The differences in CEC amounts were insignificant (Table 2).

\subsection{Content of Macro- and Micronutrients}

Plant available forms of phosphorus were within wide limits (35.77-310.68 $\mathrm{mg} \mathrm{kg}^{-1}$ ) and showed a dependence on present (sites 1,2,3) and past activities of birds (Table 3). In other studied soils, the phosphorus content was related to the progress of soil forming process and vegetation. The average content of phosphorus in studied soils was $168.01 \mathrm{mg} \mathrm{kg}^{-1}$. Phosphorus content correlated with potassium content, with the greatest amounts found in the soils at site 1 $\left(627.31 \mathrm{mg} \mathrm{kg}^{-1}\right)$. The average potassium content in studied soils amounted to $262.47 \mathrm{mg} \mathrm{kg}^{-1}$. It should be noted that the coefficients of variation for phosphorus and potassium were similar (Table 3 ), which suggests similar type of circulation and accumulation of these nutrients in the soils studied.

Table 3. Mean values of nutrients ( $\left.\mathrm{mg} \mathrm{kg}^{-1}\right)$ with standard deviation (SD) and coefficient of variation (CV, \%). In each column, significant differences observed at $p<0.05$ after the Kruskal-Wallis test followed by Dunn's posthoc test are marked by different letters.

\begin{tabular}{|c|c|c|c|c|c|c|c|c|c|c|c|}
\hline Site No. & & $\mathbf{P}$ & $\mathbf{K}$ & Mg & $\mathrm{N}-\mathrm{NO}_{3}$ & $\mathrm{~N}-\mathrm{NH}_{4}$ & $\mathbf{F e}$ & Mn & $\mathbf{Z n}$ & $\mathrm{Cu}$ & B \\
\hline \multirow[t]{3}{*}{1} & Mean & $310.68^{d}$ & $627.31^{c}$ & $268.50^{\mathrm{a}}$ & $31.19^{c}$ & $385.52^{d}$ & $4363.51^{\mathrm{abc}}$ & $85.05^{\mathrm{ab}}$ & $78.52^{d}$ & $88.67^{\mathrm{c}}$ & $2.45^{\mathrm{bc}}$ \\
\hline & SD & 13.42 & 211.05 & 99.00 & 14.49 & 59.91 & 81.60 & 28.69 & 24.18 & 19.29 & 0.47 \\
\hline & $\mathrm{CV}$ & 4.32 & 33.64 & 36.87 & 46.47 & 15.54 & 1.87 & 33.74 & 30.79 & 21.75 & 19.27 \\
\hline \multirow[t]{3}{*}{2} & Mean & $270.13^{\mathrm{cd}}$ & $357.55^{\mathrm{bc}}$ & $391.98^{\mathrm{ab}}$ & $4.73 b^{c}$ & $66.32^{\mathrm{cd}}$ & $4231.12^{\mathrm{abc}}$ & $53.55^{\mathrm{a}}$ & $62.22^{\mathrm{bcd}}$ & $75.18^{\mathrm{abc}}$ & $3.58^{\mathrm{bc}}$ \\
\hline & SD & 29.36 & 60.16 & 54.42 & 2.79 & 33.05 & 258.53 & 7.69 & 24.35 & 45.90 & 2.01 \\
\hline & $\mathrm{CV}$ & 10.87 & 16.82 & 13.88 & 59.00 & 49.83 & 6.11 & 14.28 & 39.14 & 61.05 & 56.08 \\
\hline \multirow[t]{3}{*}{3} & Mean & $247.90^{\mathrm{abcd}}$ & $252.08^{\mathrm{abc}}$ & $492.66^{\mathrm{ab}}$ & $1.62^{\mathrm{abc}}$ & $6.31^{\mathrm{abcd}}$ & $4476.07^{\mathrm{bc}}$ & $116.23^{\mathrm{abc}}$ & $24.73^{\mathrm{abcd}}$ & $53.64^{\mathrm{abc}}$ & $1.20^{\mathrm{abc}}$ \\
\hline & SD & 35.33 & 77.74 & 75.61 & 1.58 & 6.16 & 81.57 & 38.33 & 12.46 & 10.48 & 0.78 \\
\hline & $\mathrm{CV}$ & 14.25 & 30.84 & 15.35 & 98.08 & 97.66 & 1.82 & 32.97 & 50.37 & 19.54 & 65.24 \\
\hline \multirow[t]{3}{*}{4} & Mean & $65.43^{\mathrm{abc}}$ & $117.10^{\mathrm{a}}$ & $534.14^{\mathrm{b}}$ & $0.65^{\mathrm{ab}}$ & $0.24^{\mathrm{abc}}$ & $4376.02^{\mathrm{abc}}$ & $212.13^{c}$ & $10.85^{\mathrm{ab}}$ & $47.64^{\mathrm{abc}}$ & $0.31^{\mathrm{ab}}$ \\
\hline & SD & 3.37 & 11.30 & 43.72 & 0.33 & 0.08 & 46.14 & 12.84 & 0.53 & 2.56 & 0.11 \\
\hline & $\mathrm{CV}$ & 5.14 & 9.65 & 8.18 & 50.68 & 34.87 & 1.05 & 6.05 & 4.88 & 5.37 & 36.41 \\
\hline \multirow[t]{3}{*}{5} & Mean & $251.53^{\mathrm{bcd}}$ & $291.97^{\mathrm{abc}}$ & $271.84^{\mathrm{a}}$ & $1.62^{\mathrm{abc}}$ & $23.60^{\text {bcd }}$ & $4809.57^{\mathrm{c}}$ & $96.23^{\mathrm{ab}}$ & $20.23^{\mathrm{abc}}$ & $51.05^{\mathrm{abc}}$ & $11.10^{\mathrm{c}}$ \\
\hline & $\mathrm{SD}$ & 22.50 & 82.59 & 124.90 & 1.14 & 37.12 & 84.39 & 53.74 & 5.11 & 6.74 & 6.14 \\
\hline & $\mathrm{CV}$ & 8.95 & 28.29 & 45.94 & 70.05 & 157.29 & 1.75 & 55.85 & 25.23 & 13.20 & 55.34 \\
\hline \multirow[t]{3}{*}{6} & Mean & $56.29^{\mathrm{ab}}$ & $122.08^{a}$ & $535.64^{b}$ & $1.32^{\mathrm{abc}}$ & $1.16^{\mathrm{abcd}}$ & $4204.24^{\mathrm{ab}}$ & $173.55^{\mathrm{bc}}$ & $9.85^{\mathrm{a}}$ & $26.38^{\mathrm{a}}$ & $0.40^{\mathrm{ab}}$ \\
\hline & SD & 46.67 & 21.68 & 99.82 & 0.66 & 1.48 & 105.55 & 20.36 & 2.12 & 2.25 & 0.23 \\
\hline & $\mathrm{CV}$ & 82.91 & 17.76 & 18.63 & 49.75 & 127.04 & 2.51 & 11.73 & 21.53 & 8.53 & 58.23 \\
\hline \multirow[t]{3}{*}{7} & Mean & $106.33^{\mathrm{abc}}$ & $135.15^{\mathrm{ab}}$ & $314.30^{\mathrm{ab}}$ & $0.46^{\mathrm{a}}$ & $0.14^{\mathrm{a}}$ & $3747.37^{\mathrm{a}}$ & $166.87^{b c}$ & $8.00^{\mathrm{a}}$ & $62.87^{b c}$ & $0.24^{\mathrm{a}}$ \\
\hline & SD & 22.58 & 18.35 & 55.28 & 0.20 & 0.05 & 43.12 & 9.17 & 0.88 & 8.51 & 0.08 \\
\hline & $\mathrm{CV}$ & 21.24 & 13.57 & 17.59 & 43.81 & 38.81 & 1.15 & 5.50 & 10.98 & 13.53 & 35.01 \\
\hline \multirow[t]{3}{*}{8} & Mean & $35.77^{\mathrm{a}}$ & $196.53^{\mathrm{abc}}$ & $566.57^{b}$ & $0.39^{\mathrm{a}}$ & $0.19^{\mathrm{ab}}$ & $4111.61^{\mathrm{ab}}$ & $149.05^{\mathrm{abc}}$ & $72.71^{\mathrm{cd}}$ & $36.74^{\mathrm{ab}}$ & $0.38^{\mathrm{ab}}$ \\
\hline & SD & 6.77 & 80.81 & 107.42 & 0.24 & 0.04 & 147.70 & 25.63 & 43.06 & 3.14 & 0.08 \\
\hline & $\mathrm{CV}$ & 18.93 & 41.12 & 18.96 & 60.40 & 22.35 & 3.59 & 17.19 & 59.22 & 8.55 & 22.23 \\
\hline \multirow[t]{3}{*}{ All sites } & Mean & 168.01 & 262.47 & 421.95 & 5.25 & 60.43 & 4289.94 & 131.58 & 35.89 & 55.27 & 2.46 \\
\hline & SD & 108.99 & 182.74 & 143.12 & 11.12 & 128.57 & 311.07 & 56.50 & 33.90 & 25.52 & 4.09 \\
\hline & $\mathrm{CV}$ & 64.87 & 69.62 & 33.92 & 211.78 & 212.74 & 7.25 & 42.94 & 94.44 & 46.16 & 166.64 \\
\hline
\end{tabular}


The amount of plant available magnesium was the highest in the soils at site $8\left(566.57 \mathrm{mg} \mathrm{kg}^{-1}\right)$ and did not vary much. The average magnesium content in studied soils amounted to $421.95 \mathrm{mg} \mathrm{kg}^{-1}$ and CV to $33.92 \%$.

The greatest variability was noted in the nitrogen ion content - ammonium and nitrate for which the CV amounted to 211.78 and $212.74 \%$, respectively. The largest ammonium ion content was found in the soils at site 1 (385.52 $\left.\mathrm{mg} \mathrm{kg}^{-1}\right)$, less in the soils at site 2 (66.32 $\left.\mathrm{mg} \mathrm{kg}{ }^{-1}\right), 5$ (23.60 $\left.\mathrm{mg} \mathrm{kg}^{-1}\right)$ and 3 (6.31 $\left.\mathrm{mg} \mathrm{kg}^{-1}\right)$. In other soils ammonium ion content was low, less than $1.0 \mathrm{mg} \mathrm{kg}^{-1}$. It should be noted that in the soils at sites $1,2,3$, and 5 , the amount of ammonium ion was much higher than the amount of nitrate ion. In other soils the amount of nitrate ion was higher than the amount of ammonium ion.

The iron content was similar in all soils. The mean content of $\mathrm{Fe}$ in the studied soils amounted to 4289.94 $\mathrm{mg} \mathrm{kg}{ }^{-1}$ with $\mathrm{CV}$ amounting to $7.25 \%$. The average manganese content was $131.58 \mathrm{mg} \mathrm{kg}^{-1}$ and $\mathrm{CV}$ $42.94 \%$.

The amount of zinc proved to be more variable (CV 94.44\%). The elevated content of $\mathrm{Zn}$ in the soils at sites 1 and 2 (78.52 and $62.22 \mathrm{mg} \mathrm{kg}^{-1}$, respectively) could be associated with the bioaccumulation under the influence of birds (penguins). The $\mathrm{Zn}$ content in the soils at site 8 - the area around the research station $\left(72.71 \mathrm{mg} \mathrm{kg}^{-1}\right)$ could be related to fauna activity and perhaps partly to anthropopressure. The average copper content amounted to $55.27 \mathrm{mg} \mathrm{kg}^{-1}$. The highest amount of $\mathrm{Cu}$ was found in the soils at sites 1 and 2 (88.67 and $75.18 \mathrm{mg} \mathrm{kg}^{-1}$, respectively) and is associated with bioaccumulation under the influence of birds. The boron content varied greatly (CV $166.64 \%$ ). The highest amounts were observed in the soils at site $5\left(11.10 \mathrm{mg} \mathrm{kg}^{-1}\right)$ and lower in the soils at sites 1, 2 and 3. In other soils it was less than 1.0 $\mathrm{mg} \mathrm{kg}{ }^{-1}$.

\subsection{Relations between Components}

Analysis of correlation matrix (Table 4) proved that studied soils have many typical relationships, such as LOI, TOC, TN, CEC. However, as a result of low and variable content of clay fraction, this parameter was negatively correlated with some soil properties (between LOI, TOC, TN, CEC), and with concentrations of some nutrients available to plants $\left(\mathrm{P}, \mathrm{K}, \mathrm{N}-\mathrm{NO}_{3}\right.$, $\left.\mathrm{N}-\mathrm{NH}_{4}, \mathrm{Fe}, \mathrm{Cu}, \mathrm{Zn}, \mathrm{Cu}, \mathrm{B}\right)$. Similar relations were stated for silt. These relationships are different from mineral soils in temperate climate. Negative correlation between $\mathrm{pH}\left(\mathrm{H}_{2} \mathrm{O}\right)$ and $\mathrm{LOI}, \mathrm{TOC}, \mathrm{TN}$ results from the fact that the accumulation of organic matter is connected with acidification of the site, especially at low decomposition rate (Cannone et al., 2008). Strong relations were stated between concentrations of nutrients available to plants $\left(\mathrm{P}, \mathrm{K}, \mathrm{N}-\mathrm{NO}_{3}, \mathrm{~N}_{-} \mathrm{NH}_{4}\right.$, $\mathrm{Fe}, \mathrm{Zn}, \mathrm{Cu}, \mathrm{B})$ and some soil organic matter parameters (LOI, TOC, TN). In studied soils organic matter but not clay fraction is a main reservoir of nutrients. It is confirmed by a dominant accumulation of nutrients, which is a consequence of the activity of ornithofauna. However, magnesium and manganese show different relationships and they were negatively correlated with LOI, TOC and TN. High amounts of magnesium may be related to high content of $\mathrm{Mg}$ in volcanic soil material and manganese may be related to transformation and migration during redox processes. Significant correlation between phosphorus and iron $(r=0.466$, $p \leq 0.01)$ suggests adsorption of $\mathrm{P}$ by iron oxides associated with humic substances (Redel et al., 2016). 
Table 4. Linear correlation coefficients among soil properties $(n=48)$. Critical values of the correlation coefficient: 0.287 at the significance level of 0.05 , and 0.372 at the significance level of 0.01

\begin{tabular}{|c|c|c|c|c|c|c|c|c|c|c|c|c|c|c|c|c|c|c|c|}
\hline & Sand & Silt & Clay & LOI & TOC & TN & C:N & $\begin{array}{l}\mathbf{p H} \\
\left(\mathrm{H}_{2} \mathrm{O}\right)\end{array}$ & CEC & BS & $\mathbf{P}$ & $\mathbf{K}$ & Mg & $\mathrm{N}^{2}-\mathrm{NO}_{3}$ & $\mathrm{~N}-\mathrm{NH}_{4}$ & $\mathbf{F e}$ & Mn & Zn & $\mathrm{Cu}$ \\
\hline Silt & -0.999 & & & & & & & & & & & & & & & & & & \\
\hline Clay & -0.972 & 0.964 & & & & & & & & & & & & & & & & & \\
\hline LOI & 0.672 & -0.674 & -0.634 & & & & & & & & & & & & & & & & \\
\hline TOC & 0.606 & -0.609 & -0.559 & 0.952 & & & & & & & & & & & & & & & \\
\hline TN & 0.618 & -0.624 & -0.552 & 0.895 & 0.918 & & & & & & & & & & & & & & \\
\hline $\mathrm{C}: \mathrm{N}$ & -0.731 & 0.724 & 0.768 & -0.628 & -0.587 & -0.661 & & & & & & & & & & & & & \\
\hline $\mathrm{pH}\left(\mathrm{H}_{2} \mathrm{O}\right)$ & -0.630 & 0.623 & 0.671 & -0.633 & -0.653 & -0.617 & 0.765 & & & & & & & & & & & & \\
\hline CEC & 0.275 & -0.279 & -0.235 & 0.674 & 0.684 & 0.653 & -0.294 & -0.278 & & & & & & & & & & & \\
\hline BS & -0.591 & 0.581 & 0.649 & -0.557 & -0.532 & -0.412 & 0.626 & 0.817 & -0.029 & & & & & & & & & & \\
\hline $\begin{array}{l}\mathbf{P} \\
\mathbf{P}\end{array}$ & 0.631 & -0.635 & -0.580 & 0.682 & 0.701 & 0.744 & $\begin{array}{l}-0.699 \\
-0.02\end{array}$ & -0.776 & 0.257 & -0.726 & & & & & & & & & \\
\hline $\mathbf{K}$ & 0.569 & -0.573 & -0.517 & 0.499 & 0.482 & 0.699 & -0.623 & -0.455 & 0.159 & -0.399 & 0.741 & & & & & & & & \\
\hline Mg & -0.180 & 0.188 & 0.106 & -0.221 & -0.270 & -0.339 & 0.228 & 0.529 & 0.034 & 0.506 & -0.581 & -0.400 & & & & & & & \\
\hline $\mathrm{N}-\mathrm{NO}_{3}$ & 0.381 & -0.387 & -0.322 & 0.254 & 0.307 & 0.545 & -0.458 & -0.296 & -0.004 & -0.155 & 0.539 & 0.857 & -0.308 & & & & & & \\
\hline $\mathrm{N}-\mathrm{NH}_{4}$ & 0.421 & -0.427 & -0.359 & 0.297 & 0.329 & 0.601 & -0.513 & -0.408 & 0.061 & -0.201 & 0.596 & 0.869 & -0.426 & 0.931 & & & & & \\
\hline $\mathrm{Fe}$ & 0.398 & -0.379 & -0.536 & 0.420 & 0.374 & 0.285 & -0.581 & $\begin{array}{l}-0.406 \\
-0.634\end{array}$ & 0.071 & $\begin{array}{l}-0.201 \\
-0.779\end{array}$ & 0.466 & 0.319 & $\begin{array}{l}-0.420 \\
-0.091\end{array}$ & 0.139 & 0.143 & & & & \\
\hline Mn & -0.745 & 0.750 & 0.676 & -0.627 & -0.607 & -0.674 & 0.671 & 0.636 & -0.321 & 0.584 & -0.765 & -0.576 & 0.476 & -0.318 & -0.408 & -0.288 & & & \\
\hline $\mathrm{Zu}$ & 0.526 & -0.532 & -0.456 & 0.394 & 0.377 & 0.549 & -0.302 & -0.154 & 0.357 & -0.057 & 0.349 & 0.616 & -0.068 & 0.559 & 0.561 & 0.024 & -0.439 & & \\
\hline $\mathrm{Cu}$ & 0.201 & -0.210 & $\begin{array}{l}-0.450 \\
-0.118\end{array}$ & 0.497 & 0.570 & 0.703 & -0.260 & -0.341 & 0.431 & -0.199 & 0.608 & 0.662 & $\begin{array}{l}-0.410 \\
-0.40\end{array}$ & 0.604 & 0.608 & 0.148 & $\begin{array}{l}-0.3979 \\
-0.397\end{array}$ & 0.494 & \\
\hline B & 0.355 & -0.348 & -0.395 & 0.403 & 0.388 & 0.312 & -0.390 & -0.560 & 0.042 & -0.771 & 0.458 & 0.278 & -0.510 & 0.063 & 0.081 & 0.656 & -0.481 & 0.061 & 0.228 \\
\hline
\end{tabular}

Principal Component Analysis provides information about the relations between the parameters studied (represented by vectors) and the sites (represented by points). On the basis of Kaiser's criterion, four principal components with eigenvalues $>1$ were retained. The extracted principal components account for $84.64 \%$ of the total variance of the primary variables and they explain 51.38\%, 16.13\%, 9.29\% and $7.25 \%$ of the variance. Loadings define the contribution of each primary variable in a principal component. The length and direction of the vector determines to what extent each variable affects the principal components (Figure 3).

Variables with loadings $\geq 0.7$ were considered significant (Iwara et al., 2011) and loaded heavily on principal components. Third (PC 3) and fourth principal
(PC 4) components did not have loadings $\geq 0.7$. For that reason only principal component 1 (PC 1$)$ and 2 (PC 2) were taken into further consideration (Figure 3 and 4). PC 1 received the greatest loadings from $\mathrm{pH}\left(\mathrm{H}_{2} \mathrm{O}\right)(0.85)$, silt (0.83) and clay (0.82) contents, BS (0.78), TOC/TN (0.83) ratio, $\operatorname{Mn}(0.81)$ with positive effect and from sand $(-0.84)$ content, $\mathrm{H}^{+}$ $(-0.84)$, LOI (-0.83), TN (-0.84), TOC (-0.81) and $\mathrm{P}(-0.88), \mathrm{K}(-0.74)$ with negative effect, while PC 2 received the greatest loadings from $\mathrm{pH}(\mathrm{KCl})(-0.78)$. It should be noted that TOC content shows significant positive correlation with silt and clay whereas sand, hydrogen ion, boron and iron show significant negative correlation with clay, silt, TOC and $\mathrm{pH}$ values (Figure 3). 


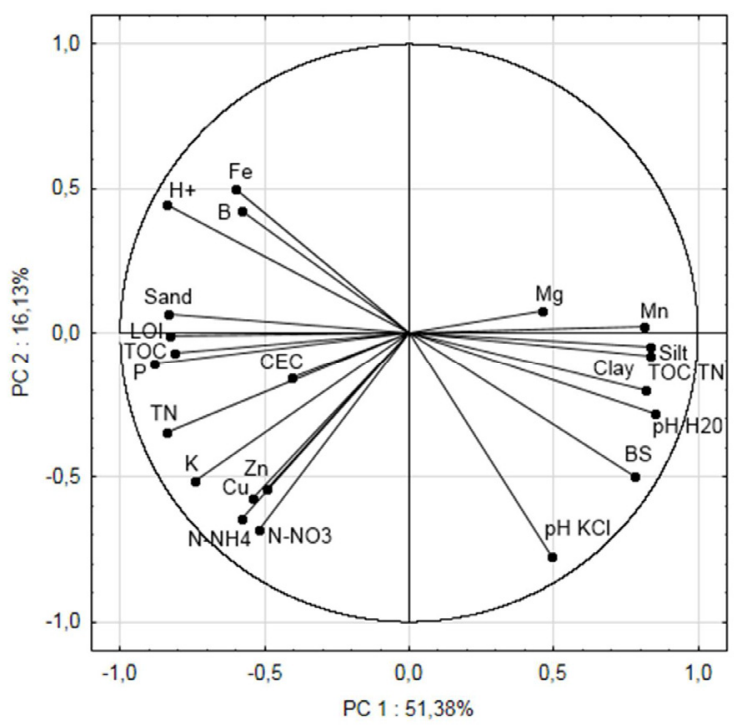

Figure 3. The plot of loadings for 22 variables in terms of principal component 1 (PC 1) and principal component 2 (PC 2).

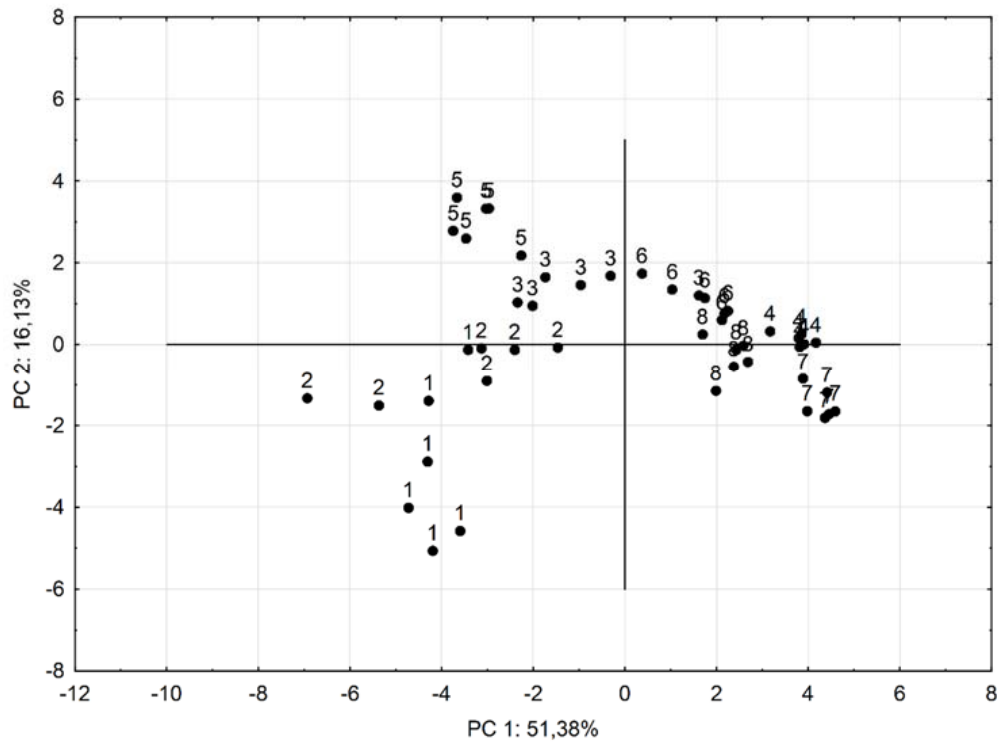

Figure 4. Score plot demonstrating the relationships between eight studied sites in terms of principal component 1 (PC 1) and principal component 2 (PC 2). 


\section{Discussion}

\subsection{Soil texture}

The studied soils were formed from unsorted parent materials and have shallow soil profiles. They cover the cracks between major rock parts (sites 1 and 2) and were classified as Leptosols. The soils at site 6 were developed on the scree debris and the other soils on the morainal postglacial sediments exposed by the glacier at different times (Table 1). Therefore, the studied soils contain high amounts of coarse fraction with diameter $>2 \mathrm{~mm}$. Studied soils contain between 45 and $73 \%$ of gravel and these contents can be ordered as follows: site $8(45 \%)>$ site $4(53 \%)>$ site $2(59 \%)>$ site $1(62 \%)$ $>$ site $5(63 \%)>$ site $6(68 \%)>$ site $7(71 \%)>$ site 3 (73\%). High amount of coarse fractions are typical for Antarctic soils (e.g. Simas et al., 2008; Francelino et al., 2011; Simas et al., 2015).

In soils of maritime Antarctica, physical weathering prevails, associated with the cryogenic processes resulting from freeze-thaw cycles. The chemical weathering is less and limited to locations with higher moisture content (Simas et al., 2008). It is the reason for the prevalence of sand fraction in finer particles (diameter less than $2 \mathrm{~mm}$ ) (Table 2). It should be noted, however, that in the soils at sites 4 and 7 formed on moraines, and classified as Regosols, the proportion of the silt fraction is higher, which in polar regions is connected to frost weathering. The clay fraction is low, which is associated with the young age of sediments/soils and low intensity of chemical weathering. Similar clay content in the soils of the polar zone was found by Vlasov et al. (2005), Cannone et al. (2008) and Smykla et al. (2015). From Principal Component Analysis it can be concluded that silt and clay contents are positively correlated with base saturation and negatively with exchangeable hydrogen. However, they are not correlated with cation exchange capacity (Figure 3 ). The $\mathrm{pH}$ values are also negatively correlated with exchangeable hydrogen, iron and boron.

\subsection{Variability of nutrient content}

The soil sampling scheme applied in the study enables comparison of the variability of the studied parameters within eight sites. Lithology and parent material is similar in the study area, therefore the variability of the studied soil parameters can be attributed to environmental variation and interaction between abiotic and biotic factors. Considerable variation in soil properties both between the study sites and within the sites was noted. The soil parameters change within, as well as among, the studied sites (Table 2, 3). Differentiation within the sites results from the specificity of soils that are formed in crevices of rocks. The large spatial variability of soils in the polar region is emphasized in the literature (e.g. Smykla et al., 2015). Short-range soil variability in a $10 \times 10 \mathrm{~m}$ square was depicted by Beyer et al. (2000).

For most studied sites, the coefficient of variation for $\mathrm{pH}, \mathrm{CEC}$ and BS was below $15 \%$, which is low, according to the scheme proposed by Wilding and Drees (1983). Higher variability was found for the parameters related to organic matter (LOI, TOC, TN, TOC/ $\mathrm{TN}$ ratio) for which the $\mathrm{CV}$ was in the range of 15 $35 \%$, i.e. moderate, or even above $35 \%$, i.e. high. The variability of the parameters describing the accumulation of organic matter can be attributed to the diversity of environmental conditions, including vegetation, and to the impact of birds. It should be noted that the soils at sites 2, 3 and 5 demonstrated high CV values. Similar trends were noted for the biophilous compounds, especially for the nitrogen compounds $\left(\mathrm{N}-\mathrm{NO}_{3}\right.$ and $\mathrm{N}-\mathrm{NH}_{4}$ ). The soils that have been under the influence of current or former birds colonies have higher variability of soil biophilous compounds than other studied soils. These compounds accumulate in the soils 
near the colonies, dissolve in water, then migrate and disperse in the surrounding area. The described processes can be intense, despite periodic lack of water, as the studied sites are located on steep slopes (Table 1). In terms of variability, the investigated soil properties can be classed as stable (conservative), having a low value of $\mathrm{CV}$ and a strong relationship with the parent material and slowly changing with time. The parameters are: particle size, soil reaction, sorptive properties (CEC, BS) and some chemical properties - the content of iron and manganese. More variable parameters relate to the accumulation of organic matter and nutrients. High CV values indicate the impact of avifauna on soil. The coefficient of variation also has practical implications, namely that it is related to the number of samples required to determine arithmetic mean values or to demonstrate the significance of differences between sites (objects) (Wilding and Drees, 1983).

\subsection{Nutrient abundance}

In most of the studied soils the amount of plant-available phosphorous is high or even very high (sites 1,2 , $3,5,7)$ and mean amounts are 2-3-fold higher than the value regarded as high for soils $\left(89 \mathrm{mg} \mathrm{P} \mathrm{kg}^{-1}\right)$. Even soils that were uncovered by the glacier only several decades ago (site 7 - the youngest moraine of Ecology Glacier), contain high amounts of P. A similar tendency can be seen for potassium. It is assumed that in sandy soils the amount of 105 to $145 \mathrm{mg} \mathrm{K} \mathrm{kg}^{-1}$ is high. Beside avian influence, potassium in soils is also related to the content of $\mathrm{K}$ in bedrock and to weathering of bedrock (Poelking et al., 2015).

Plant-available magnesium is very high (more than $61 \mathrm{mg} \mathrm{kg}^{-1}$ ), which can be attributed to the character of the parent rocks which are basalts and basaltic andesits rich in magnesium and typical of this part of Antarctica (Lee et al., 2004). The amount of zinc is related to avian influence and is the highest at sites 1 ,
2 and 8. Enrichment in $\mathrm{Zn}$ is related to the transfer of this compound from the sea through the food chain (Michel et al., 2006). The amount of plant-available copper is also high, especially at sites 1 and 2, influenced by ornithofauna.

The amount of plant-available nutrients in studied soils is comparable with arable soils of the temperate climate. However, soils affected by birds, especially of site 1 and 2 can be assessed as extremely over-fertilized by phosphorus. It is assumed that the eolian deposition sourced from soils influenced by penguins contributed to elevated status of plant available macro- and micronutrients in soils not directly affected by ornithofauna (e.g. Beyer et al., 2000; Lee et al., 2004).

\subsection{Nutrients and soil development}

Among the studied sites, two soil groups can be distinguished. The first includes weakly developed soils, whose origin is associated with the accumulation of organic matter mainly of vegetation origin, including algae, lichens and mosses - sites 4, 6, 7 and 8 . The organic matter content (LOI) in these soil ranges from 2.33 to $4.50 \%$. The second group of soils includes Leptosols (sites 1 and 2) and Cryosols (sites 3 and 5) developed under the influence of current or former bird colonies. These soils contain much more organic matter (LOI from 6.36 to $12.46 \%$ ) and more nutrients (Table 2 and 3). Similar relationships were expressed in the Principal Component Analysis (Figure 4). The literature highlights the profound impact of avifauna on the transport of nutrients from sea to land (Simas et al., 2008). Piscivorous birds play a very important role in the circulation of nutrients such as $\mathrm{N}, \mathrm{P}$ and $\mathrm{K}$ between aquatic and terrestrial ecosystems (Ligęza and Smal, 2003). 
Ornithogenic soils, due to the large nutrient content, are different from other polar soils which are poor in nutrients (Cannone et al., 2008). The amounts of nitrogen and other nutrients in ornithogenic soils are affected by the processes of leaching and dispersion. Under the humid maritime climate, there is a water percolation and lateral movement of the P-rich leachates (Simas et al., 2008). The increased content of TN in the soil under the influence of avifauna leads to a narrowing of TOC/TN ratio. The lowest ratio was found in the soils at sites 1 and 2, and the highest for the soils at sites 3, 5 and 6 . A TOC/TN ratio below 20 indicates favourable conditions for organic matter decomposition and mineralization of organic nitrogen compounds. The widest TOC/TN ratio (50.82) was found in soils at site 7 (the youngest moraine of Ecology Glacier). This suggests very low nitrogen content, typical of soils formed on early deglaciated areas. It is estimated that glacial retreat exposed such soils approx. 30 years ago. In contrast, exposure of the deposits at the II moraine of Ecology Glacier took place over 100 years ago (Birkenmajer, 2002; Pudełko, 2002). Generally, TOC/TN ratio depends on the age of soils and it narrows down when the soil is developed under plant cover. It is related to the accumulation of nitrogen in humus compounds (Abakumov, 2010). Therefore, the youngest soil of site 7 (The Youngest MEG) had TOC/TN ratio amounting to 50.82 on average, and the oldest soil at site 4 (II MEG) had TOC/TN ratio of 34.59 on average. The soil at site 8 , which had low TVC (55\%), had a wide TOC/TN ratio (37.24) as a result of mechanic disturbance of plant cover.

\section{Conclusions}

This study demonstrates that the advancement of soil forming processes, as well as the development of soil properties, are dependent on the interaction between abiotic and biotic factors, of which bird colonies are the most important. This in turn determines the growth of vegetation and accumulation of organic matter crucial for the development of soils.

The amounts of plant available elements were high in all studied soils. The amounts of N, P, K and Zn were related to the activity of ornithofauna. The amounts of studied elements in ornithogenic soils were several times higher than in most mineral soils with sandy bedrock of temperate zones. The amounts of elements in soils that were recently uncovered by the glacier is related to the dispersion of biogens by wind and activity of skua. The soils of marine zones of Antarctica can be treated as a pivotal reservoir of biogens, which can be released as a result of climatic changes.

\section{Acknowledgements}

This research was supported by the Polish Ministry of Scientific Research and Higher Education, grant no. NN 303796240 and research project of University of Warmia and Mazury in Olsztyn No. 20.610.007-300. We would like to thank Mary N. Scherbatskoy (Blackland Centre, Scotland) for corrections made to the text.

\section{References}

Abakumov, E.V. 2010. The sources and composition of humus in some soils of West Antarctica. Euras. Soil Sci. 43, 499-508.

Androsiuk, P., Chwedorzewska, K., Szandar, K., Giełwanowska, I. 2015. Genetic variation of Colobanthus quitensis from King Georgie Island (Antarctic). Pol. Polar Res. 36, 281-295.

Beyer, L., Bölter, M. 2012. Geoecology of Antarctic Ice-Free Coastal Landscapes. Springer. 429 pp. 
Birkenmajer, K. 2002. Retreat of the Ecology Glacier, Admiralty Bay, King George Island (South Shetland Islands, West Antarctica), 1956-2001. B. Pol. Acad. Sci.-Earth. 50, 15-29.

Bölter, M. 2011. Soil development and soil biology on King George Island, Maritime Antarctic. Pol. Polar Res. 32, 105-116.

Cannone, N., Wagner, D., Hubberten, H.W., Guglielmin, M. 2008. Biotic and abiotic factors influencing soil properties across a latitudinal gradient in Victoria Land, Antarctica. Geoderma. 144, 50-65.

Carvajal, A.M., Vargas, R.A., Alfaro, M. 2016. Abundance of denitrifying genes and microbial community structure in volcanic soils. J. Soil Sci. Plant Nutr. 16, 677-688.

Egnér, H., Riehm, H., Domingo, W.R. 1960. Untersuchungen über die chemische Bodenanalyse als Grundlage für die Beurteilung des Nährstoffzustandes des Bodens. II. Chemische Extraktionsmethoden zur Phosphor- und Kaliumbestimmung. Kungliga Lantbrukshögskolans Annaler. 26, 204-209.

Fotyma, M., Dobers, E.S. 2008. Soil testing methods and fertilizer recommendations in Central-Eastern European countries. Fertilizers and Fertilization. 30, 6-93.

Francelino, M.R., Schaefer, C.E.G.R., Simas, F.N.B., Fernandes Filho, E.I., de Souza, J.J.L.L., da Costa, L.M. 2011. Geomorphology and soils distribution under paraglacial conditions in an ice-free area of Admiralty Bay, King George Island, Antarctica. Catena. 85, 194-204.

Hughes, K.A., Pertierra, L.R., Molina-Montenegro, M.A., Convey, P. 2015. Biological invasions in terrestrial Antarctica: what is the current status and can we respond? Biodivers. Conserv. 24, 1031-1055.
IUSS Working Group WRB. 2015. World reference base for soil resources 2014, update 2015. International soil classification system for naming soils and creating legends for soil maps. Food and Agriculture Organization of the United Nations, Rome. 190 pp.

Iwara, A.I., Ogundele, F.O., Ibor, U.W., Deekor, T.N. 2011. Multivariate analysis of soil-vegetation interrelationships in a south-southern secondary forest of Nigeria. Int. J. Biol. 3, 73-82.

Kabała, C., Zapart, J. 2012. Initial soil development and carbon accumulation on moraines of the rapidly retreating Werenskiold Glacier, SW Spitsbergen, Svalbard archipelago. Geoderma. 175-176, 9-20.

Lee, Y.I., Lim, H.S., Yoon, H.I. 2004. Geochemistry of soils of King George Island, South Shetland Islands, West Antarctica: Implications for pedogenesis in cold polar regions. Geoch. et Cosmoch. Acta. 68, 4319-4333.

Ligęza, S., Smal, H. 2003. Accumulation of nutrients in soils affected by perennial colonies of piscivorous birds with reference to biogeochemical cycles of elements. Chemosphere. 52, 595-602.

Michel, R.F.M., Schaefer, C.E.G.R., Dias, L.E., Simas, F.N.B., de Melo Benites, V., de Sá Mendonça, E. 2006. Ornithogenic Gelisols (Cryosols) from Maritime Antarctica: pedogenesis, vegetation, and carbon studies. Soil Sci. Soc. Am. J. 70, 1370-1376.

Nędzarek, A. 2008. Sources, diversity and circulation of biogenic compounds in Admiralty Bay, King George Island, Antarctica. Antarct. Sci. 20, 135-145.

Otero, X.L., Fernández, S., de Pablo Hernandez, M.A., Nizoli, E.C., Quesada, A. 2013. Plant communities as a key factor in biogeochemical processes involving micronutrients ( $\mathrm{Fe}, \mathrm{Mn}, \mathrm{Co}$, and $\mathrm{Cu}$ ) in Antarctic soils (Byers Peninsula, maritime Antarctica). Geoderma. 195-196, 145-154. 
Pereira, T.T.C., Schaefer, C.E.G.R., Ker, J.C., Almeida, C.C., Almeida, I.C.C. 2013. Micromorphological and microchemical indicators of pedogenesis in Ornithogenic Cryosols (Gelisols) of Hope Bay, Antarctic Peninsula. Geoderma. 193-194, 311-322.

Ping, C.L., Jastrow, J.D., Jorgenson, M.T., Michaelson, G.J., Shur, Y.L. 2015. Permafrost soils and carbon cycling. Soil. 1, 147-171.

Poelking, E.L., Schaefer, C.E.R., Fernandes Filho, E.I., de Andrade, A.M., Spielmann, A.A. 2015. Soil - landform - plant-community relationships of a periglacial landscape on Potter Peninsula, maritime Antarctica. Solid Earth. 6, 583-594.

Pudełko, R. 2002. Site of Special Scientific Interest No. 8 (SSSI -8 ), King George Island, (map 1:12,500 scale), Department of Antarctic Biology, Warsaw.

Redel, Y., Cartes, P., Demanet, R., Velásquez, G., Poblete-Grant, P., Bol, R., Mora, M.L. 2016. Assessment of phosphorus status influenced by $\mathrm{Al}$ and $\mathrm{Fe}$ compounds in volcanic grassland soils. J. Soil Sci. Plant Nutr. 16, 490-506.

Simas, F.N.B., Schaefer, C.E.G.R., Albuquerque Filho, M.R., Francelino, M.R., Fernandes Filho, E.I., da Costa, L.M. 2008. Genesis, properties and classification of Cryosols from Admiralty Bay, maritime Antarctica. Geoderma. 144, 116-122.

Simas, F.N.B., Schaefer, C.E.G.R., Michel, R.F.M., Francelino, M.R., Bockheim, J.G. 2015. Soils of the South Orkney and South Shetland Islands, Antarctica. The Soils of Antarctica. In: J.G. Bockheim (ed). Springer International Publishing. Pp. 227-273.
Smykla, J., Drewnik, M., Szarek-Gwiazda, E., Siang Hii, Y., Knap, W., Emslie, S.D. 2015. Variation in the characteristics and development of soils at Edmonson Point due to abiotic and biotic factors, northern Victoria Land, Antarctica. Catena. $132,56-67$.

Świtoniak, M., Melke, J., Bartmiński, P. 2014. The differences in cellulolytic activity of the Arctic soils of Calypsostranda, Spitsbergen. Polar Record. 50, 199-208.

Tatur, A., Myrcha, A. 1984. Ornithogenic soils on King George Island, South Shetland Island (Maritime Antarctic Zone). Pol. Polar Res. 5, 31-60.

Ugolini, F.C., Bockheim, J.G. 2008. Antarctic soils and soil formation in a changing environment: A review. Geoderma. 144, 1-8.

van Reeuwijk, L.P. 2002. Procedures for soil analysis, sixth ed. Technical Papers 9, Wageningen, the Netherlands, ISRIC - World Soil Information.

Vlasov, D.Y., Abakumov, E.V., Nadporozhskaya, M.A., Kovsh, N.V., Krylenkov, V.A., Lukin, V.V., Safronova, E.V. 2005. Lithosols of King George Island, Western Antarctica. Euras. Soil Sci. 38, 681-687.

Wilding, L.P., Drees, L.R. 1983. Spatial variability and pedology, In: L.P., Wilding, N.E., Smeck, G.F. Hall (eds). Pedogenesis and Soil Taxonomy, I Concepts and Interactions, Developments in soil science 11A. Elsevier Science Publishers B.V., Amsterdam. Pp. 83-116. 